\title{
Characterization of Undergraduate Students in Nursing from a Public University
}

\begin{abstract}
Sayonnara Ferreira Maia1, Benevina Maria Vilar Teixeira Nunes ${ }^{1,5}$, Priscila de Oliveira Soares ${ }^{1}$, Elizabeth Soares Oliveira de Holanda Monteiro ${ }^{1,2}$, Girzia Sammya Tajra Rocha1,3, Lourival Gomes da Silva Júnior ${ }^{1,4}$, Erika Wanessa Oliveira Furtado ${ }^{1}$, Jéssyca Stherllany Rosendo Lima ${ }^{1}$
\end{abstract}

\section{Abstract}

Objective: to analyze the profile of the Undergraduates from the Nursing's course of a higher education institution.

Methods: a descriptive, cross-sectional study, conducted with 104 undergraduate students of the Federal University of Piauí, qualified between 2009 and 2011. The data were collected from January to March 2014, using a questionnaire.

Results: it was found that most undergraduate students are young, female, single, childless and with an average monthly income of $R \$$ $3,409.80$. Most sought professional development through postgraduate courses. As for professional practice, most worked in healthcare $(77.2 \%)$, mainly in the hospital $(46.4 \%)$. The practice of nursing care systematization was reported by $65.8 \%$ of the respondents, but they did not meet all the steps.

Conclusion: the studies with undergraduates should be done periodically to allow reflections, changes, and/or improvements in the curriculum and in the teaching-learning process of undergraduate of nursing courses in the whole country.

\section{Introduction}

Nursing training in Brazil has been historically transforming, under the influence of the educational and health policies that direct the
1 Post-Graduate Program in Nursing/ PPGENF, Federal University of Piauí/ UFPI. Teresina (PI), Brazil.

2 Department of Nursing. Estácio College, CEUT, Teresina (PI), Brazil.

3 Collegiate of Nursing, Binational Campuses of Oiapoque. Federal University of Amapá/ UNIFAP.

4 Federal Institute of Piauí, Valença (PI), Brazil.

5 Department of Nursing. Federal University of Piauí/UFPI, Teresina (PI), Brazil.

Contact information:

Elizabeth Soares Oliveira de Holanda Monteiro.

$\equiv$ elizahm@terra.com.br

Keywords

Education; Nursing; Education; Nursing; Diploma Programs; Nursing Research; Education; Higher. 
undergraduate courses in nursing, in building their educational and training projects for the nurse profile. The National Curriculum Guidelines (NCG) guides the assumptions of the undergraduate course curriculum, which define the contents, competences and general skills inherent to the profile of Bachelor in nursing [1-2].

It is understood that to reach the profile of nursing undergraduate, the educational institutions need to perform continuously adjustments in their teaching-learning practices, in order to get closer to the characteristics of the future nurse, adjusted to the social, political and individual demands.

Given this, raising information on the reality of undergraduates offers a reflection on the training process in nursing and contributes to improving the pedagogical strategies for vocational training. When searching on undergraduates, the higher education institutions (HEls) have the opportunity to check their curriculum utilization and identify obstacles to academic performance. When studying the undergraduates as professionals, it is possible to check if the profile established in the educational project has been achieved, and if the personal expectations and needs and those of the labor market are met [3-8].

Thus, it is understandable that the undergraduate represents the product of HEls, and their resourcefulness in the labor market is in one of the parameters related to teaching quality. Their systematic monitoring and the knowledge related to their profile are instruments that stimulate discussions on the method and the quality regarding the teachinglearning process, and should be appreciated during the academic training $[5,9]$.

In this perspective, the undergraduate program in nursing in the Federal University of Piauí, in theory, still did not performed studies on their undergraduates, and this need is felt, whereas the pedagogic project of the course has been passing through adaptations on the changes related to the educational and healthcare policies.
It should be noted that effective Course Pedagogic Project mentions that the assessment of nurses graduated from the institution must be carried out by means of questionnaires applied to the undergraduates, that are active or not in the labor market [10]. However, in elaborating the curriculum process no records were found as for using the results of studies with its undergraduates, which could guide reflections and changes in the pedagogical practices and in their content.

Given this situation, the following question arises: What are the socio-economic, demographic, and professional characteristics of the undergraduates from the Undergraduate Program in Nursing at the Federal University of Piauí?

Thus, this study aims to characterize the nursing undergraduates from the Undergraduate Program in Nursing at the Federal University of Piauí, undergraduate in the period, 2009 to 2011, which experienced the first Pedagogical Project of the Course, prepared based on the DCN/2001.

\section{Methods}

Cross-sectional descriptive design, developed in a federal public University in the northeast of Brazil, in the period from May to September 2013. The population of the study covered 140 Bachelor's Degree in Nursing undergraduates of from the campus in the capital, which have completed under graduation in the years, 2009 to 2011, under the period of the first pedagogical political project, implemented in 2007 and prepared as per guidelines for the National Curriculum Guidelines.

The sampling was non-probabilistic, of the convenience type. The undergraduates that met the following inclusion criteria composed the sample: have at least one year of undergraduate and acting professionally in the nursing/health field. Those not located after three contact attempts were excluded. Thus, the sample was composed of 30 undergraduates from 2009, 42 from 2010 and 32 from 2011, totaling 104 participants. 
To collect data, a questionnaire was used having four sections, face validated by a panel of experts and previously tested, containing socioeconomic characteristics: gender, age, marital status, number of children, individual monthly income, and place of residency. The second section referred to the academic and professional training: participation in complementary activities in the undergraduate program, post-graduate courses, improvement courses and scientific events, scientific papers or another degree.

The questionnaire also included items related to the professional experience, such as current occupation as a nurse, feeling as for to the choice of profession and professional achievement, using the nursing process and its steps, membership in professional associations, means used to address deficits of knowledge, development of activities in multidisciplinary team and in the community. The fourth section understood the contribution of the Nursing degree course in developing specific skills of the nurse, whose items were answered in Likert scale of 5 points, with the following levels: (1) none, (2) few, (3) average, (4) large and (5) very large.

To capture the undergraduates, one requested from the Coordination of CGE/UFPI the nominal list of undergraduates, which was answered, after release by the Head of the Department of Nursing. No private information of undergraduates was requested, such as address, phone, or email, it was just possible to verify the entry year, the year of completion, and the full name of the former student. The searches took place in the institution's Nursing Department in order to locate undergraduates who maintained ties, inserted in post-graduate programs or in the teaching staff. One also searched through internet social networks, like Facebook and Twitter. The location of a former student allowed finding others who were of the same social conviviality. The letter-invitation to participate in the research and with instructions, the counterparts of the assent term and the question- naire were delivered by means of personal meeting, physical post office, or e-mail. In the third situation, the signature was scanned.

Data were processed in the software Statistical Package for the Social Sciences (SPSS) version 18.0, and descriptive statistics were calculated, such as averages, standard deviation, minimum and maximum values for quantitative variables and frequencies for the quality-related ones.

At the study's entire step, the ethical principles cleared in Resolution No. 466/2012 of the National Health Council were respected, and also the international standards for research with human beings. The Research Ethics Committee, under written opinion No. 239.242/2013, approved it. All participants signed a Free and Clarified Consent Form in two counterparts.

\section{Results}

In Table 1, there are the socio-demographic and economic information of the undergraduates, in which $70.2 \%$ are female, $76.9 \%$ declared themselves as unmarried, $92.2 \%$ do not have children, and $78.8 \%$ have fixed residence in the capital. The average age of the participants was 26.4 years. As

Table 1. Distribution of undergraduates of the Undergraduate Program in Nursing, 2009 2011 according to the socio-demographic and economic characteristics. Teresina, PI, Brazil, 2014.

\begin{tabular}{|l|l|c|}
\hline \multicolumn{1}{|c|}{ Variables } & N & \% \\
\hline Gender & \multicolumn{3}{c|}{} \\
\hline Male & 31 & 29.8 \\
\hline Female & 73 & 70.2 \\
\hline Age group & & \\
\hline 20-25 years & 40 & 38.5 \\
\hline 26-30 years & 57 & 54.8 \\
\hline 230 years & 07 & 6.7 \\
\hline Average (D. P) & \multicolumn{2}{|c|}{$26.4(3.0)$} \\
\hline Min-Max & \multicolumn{2}{|c|}{$23-45$} \\
\hline
\end{tabular}




\begin{tabular}{|c|c|c|}
\hline Variables & $N$ & $\%$ \\
\hline \multicolumn{3}{|l|}{ Civil state } \\
\hline Single/Divorced/Widower & 80 & 76.9 \\
\hline Married/Stable Union & 24 & 23.1 \\
\hline \multicolumn{3}{|l|}{ Children } \\
\hline Yes & 08 & 7.8 \\
\hline No & 96 & 92.2 \\
\hline \multicolumn{3}{|l|}{ Current residence } \\
\hline Capital & 82 & 78.8 \\
\hline State Inland & 06 & 5.8 \\
\hline Other States & 16 & 15.4 \\
\hline \multicolumn{3}{|l|}{ Individual income } \\
\hline$<2 \mathrm{MW}$ & 07 & 6.7 \\
\hline 2 to $<4 \mathrm{MW}$ & 26 & 25.0 \\
\hline 4 to $<6 \mathrm{MW}$ & 26 & 25.0 \\
\hline$\geq 6 \mathrm{MW}$ & 27 & 26.0 \\
\hline Unanswered/Uninformed & 18 & 17.3 \\
\hline Average (S. D) & \multicolumn{2}{|c|}{$3409.80(1729.2)$} \\
\hline Min-Max & \multicolumn{2}{|c|}{$400.00-8.500 .00$} \\
\hline Total & 104 & 100.0 \\
\hline
\end{tabular}

for the average monthly income, it was 3,409.80 reals.

In Table 2, it is observed that among the 104 participants, $82.7 \%$ did or do post-graduate work. Of those, $68.6 \%$ have a completed lato sensu specialization. Concerning the other modalities of postgraduation, master's degree was the most cited, with $18.6 \%$ of undergraduates with in course under progress $4.7 \%$ with concluded Master's degree.

As for professional performance, $74.0 \%$ of undergraduates were working as a nurse, $13.4 \%$ developed labor activities in other areas, and 19.2\% were not involved in any labor activity.

As for the employment ties, the undergraduates mentioned a total of 196 jobs as a nurse, between old and current ones. At the time of data collection, $70.9 \%$ of undergraduates that acted as a nurse had only one job, and $26.7 \%$ had two or more jobs. The tie in the Hospital area was the most frequent, with $46.4 \%$; followed by the Pu-
Table 2. Distribution of undergraduates of the Undergraduate Program in Nursing, 20092011, as for performing undergraduate program. Teresina, PI, Brazil, 2014.

\begin{tabular}{|l|c|c|}
\hline \multicolumn{1}{|c|}{ Variables } & n & $\%$ \\
\hline Did/Does post-graduation & & \\
\hline Yes & 86 & 82.7 \\
\hline No & 18 & 17.3 \\
\hline Post-graduation \# & & \\
\hline Specialization (360h) completed & 59 & 68.6 \\
\hline Specialization in progress & 26 & 32.6 \\
\hline Residency completed & 01 & 1.2 \\
\hline Residency in progress & 04 & 4.7 \\
\hline Master's degree completed & 04 & 4.7 \\
\hline Master's degree in progress & 16 & 18.6 \\
\hline PhD in progress & 01 & 1.2 \\
\hline \#: Multiple Response; *: Percentages regarding the number \\
\hline \multicolumn{1}{|c|}{ of participants who did/do post-graduation (n=86). }
\end{tabular}

Table 3. Areas of professional activity, place and time of permanence in employment of undergraduates from the Undergraduate Program in nursing, 2009-2011, that act/acted as a nurse. $(n=79)$. Teresina, PI, Brazil, 2014.

\begin{tabular}{|l|c|c|}
\multicolumn{1}{|c|}{ Variables } & $\mathbf{n}$ & $\%$ \\
\hline Performance Areas & \multicolumn{2}{c|}{} \\
\hline Hospital & 91 & 46.4 \\
\hline Public health & 46 & 23.5 \\
\hline Vocational education & 32 & 16.3 \\
\hline Higher education & 11 & 5.6 \\
\hline Outpatient clinic & 06 & 3.1 \\
\hline Another area & 10 & 5.1 \\
\hline Place of performance & & \\
\hline Capital & 91 & 46.4 \\
\hline Inland & 47 & 24.0 \\
\hline Another State & 31 & 15.8 \\
\hline Did not answer/Not informed & 27 & 13.8 \\
\hline Unanswered/Uninformed & 18 & 17.3 \\
\hline Period of stay (months) & \multicolumn{2}{|c|}{12.7 (3.9) } \\
\hline Average (S. D) & \multicolumn{2}{|c|}{$1-53$} \\
\hline Min-Max & 196 & 100.0 \\
\hline Total
\end{tabular}


blic Health areas (23.5\%) and Vocational Education (16.3\%). The average time of permanence in the employment was 12.7 months, and the State's capital was the most cited as a professional activity site (46.4\%) (Table 3 ).

As for the predominant activity in the professional performance of undergraduates, the welfare function was referred to most frequently and mentioned by $77.2 \%$ of the participants in the survey. Managerial and teaching activities were both $16.5 \%$.

The undergraduates acting in health care were questioned as to the execution of Nursing Care Systematization (NCS) in their work environment. And $65.8 \%$ said doing it. It was also asked, still, among those who claimed to perform NCS, on which steps they performed, and 100\% of affirmative responses were obtained for "History/Data Collection" phase, $84.6 \%$ for "Planning", $80.8 \%$ for Prescription/Implementation, 69.2\% for "Assessment", and, finally, "Diagnosis", with $65.4 \%$ periodicity (Table 4).

About the participation of undergraduates in professional associations, it was also found that

Table 4. Distribution of undergraduates of the Undergraduate Program in Nursing, 20092011, as for performing the NCS $(n=79)$. Teresina, PI, Brazil, 2014.

\begin{tabular}{|c|c|c|}
\hline Variables & $\mathbf{n}$ & $\%$ \\
\hline Variables & N & $\%$ \\
\hline \multicolumn{3}{|l|}{ Accomplishment of NCS } \\
\hline Yes & 52 & 65.8 \\
\hline No & 19 & 24.1 \\
\hline Did not answer/Not informed & 08 & 10.1 \\
\hline \multicolumn{3}{|l|}{ Steps of NCS \#* } \\
\hline History/Nursing Data Collection & 52 & 100.0 \\
\hline Nursing diagnosis & 34 & 65.4 \\
\hline Planning & 44 & 84.6 \\
\hline Nursing Implementation/Prescription & 42 & 80.8 \\
\hline Assessment/Development of Nursing & 36 & 69.2 \\
\hline \multicolumn{3}{|c|}{$\begin{array}{l}\text { \#: Multiple choice answer; *: Percentages regarding the } \\
\text { number of participants who claimed to perform NCS } \\
\qquad(n=52) .\end{array}$} \\
\hline
\end{tabular}

$20.3 \%$ of nurses were linked to ABEn and Unions, and $60.8 \%$ claimed to not being associated with any class entity (Table 5).

Table 5. Distribution of undergraduates of the Undergraduate Program in Nursing, 20092011, as for class entity association $(n=79)$. Teresina, PI, Brazil, 2014.

\begin{tabular}{|l|c|c|}
\hline \multicolumn{1}{|c|}{ Class entities \# } & N & $\%$ \\
\hline ABEn & 16 & 20.3 \\
\hline Union & 16 & 20.3 \\
\hline Others & 01 & 1.3 \\
\hline None & 48 & 60.8 \\
\hline
\end{tabular}

\section{Discussion}

As for the socioeconomic and demographic profile of undergraduates, there is a relationship with the results of other studies that addressed nursing undergraduates that had between two to six years of training, and their results brought a profile of young, female, single, and childless majority $[9,11$, 13].

The predominance of women in nursing is something already expected, because it is a reality imbricated in the past history of this profession. On the higher frequency of singles and childless nurses, this study corroborates the thought of the researchers who have studied this subject, in which women, and in this survey, men too, are postponing marriage and children increasingly, to prioritize the career $[9,11]$.

Regarding the age of the participants, age groups revealed in the study demonstrate the prevalence of young adults among the undergraduates. This fact indicates that the entry in the CGE/UFPI happened before the age of 20 years for most respondents. Among the places of residency mentioned by participants, one highlighted the city of Teresina, a fact that can be attributed to the higher concentration of job opportunities found in the capital. 
As for the average monthly remuneration found among the respondents, that is $R \$ 3,409.80$, which is above the national average obtained by the Applied Economic Research Institute [14], which fluctuated from $R \$ 2,829.28$ to $R \$ 3,096.90$ for the nursing profession. However, the wage variation found in this research, which alternate between two to six minimum wages is highlighted. Other studies have also shown differences in remuneration for undergraduate nurses, with proceeds going from one to six minimum wages $[3,13,15]$. It is believed that the remuneration for the nurse can differentiate a lot for every job and region of performance.

With regard to the vocational training, the undergraduates in this study have shown concern and interest in their development, since that considerable number of participants did or was doing post-graduate courses. Among the post-graduate degrees cited, the insertion in specialization courses was higher, followed by master's degree and residency.

Researches on nursing undergraduates who investigated these variables also showed similar results, with significant participation of nurses in specialization courses and, in a smaller proportion, master's degree and residency $[3,6,11,13]$.

However, the discrete participation of the undergraduates of CGE/UFPI in stricto sensu courses such as master's and PhD degrees, which are important courses for insights in the area of nursing researches and for the training of teachers draws attention [in view of the growing expansion of undergraduate courses in nursing in Brazil, and the consequent need for qualified teachers]. It is inferred that the period of undergraduate training, three to five years, interferes in their insertion in the master's and PhD courses, mainly because it requires intellectual preparation and professional maturity.

Under another perspective, the job market for nursing displays a wide variety of practice areas, and constant renewal of knowledge arising from technological advances in health, and this requires trained professionals to work in this scenario.
In this way, to enter the labor market the undergraduate needs to seek knowledge that go beyond basic training, which could be decisive in competition for employment [16]. In addition, the growth of undergraduate courses in nursing increases the number of nurses in the job market every year, which raises the competition in the labor market's offers, which may be determined by the degree of training and professional skill.

With respect to the professional practice of undergraduates, the results showed that most managed to enter in the labor market, properly in nursing, however, the number of nurses without any professional activity was highlighted.

The findings in this research are matching other studies, that found similar situations as for the integration of undergraduates in the labor market: most worked as a nurse and, a smaller portion, both performed industrial activities carried on outside the training in nursing or not exercised any professional activity [3, 9, 16, 19].

As for the practice areas of the undergraduates who worked as a nurse, the hospital area was highlighted, which involved nearly half of the cited jobs. The areas of public health and vocational education were also referred in a relevant manner, and performance in higher education had little emphasis.

Other researchers found results with indexes close to this study, where the nursing undergraduates mentioned more often hospital jobs, followed by public healthcare and vocational study jobs $[9,11$, 13, 17].

Given the results, although changes have occurred in the context of health directed towards the emphasis on public health and, consequently, the emergence of new jobs in this sector, there will be more job opportunities to the nurse in the hospital area.

In this way, the construction of Teaching Projects for the graduation courses in nursing should consider this information, considering that in the recent years the higher education of nursing directed their 
curricula for primary care, assistance, with knowledge focused on promoting and protecting health.

These statements do not mean that the transition from the of health care model and of the curricula of nursing courses, which occurred in the recent decades, was not important and necessary, but that it is necessary to consider that most of the undergraduates are absorbed by the hospital area when entering the labor market; therefore, it is necessary to prepare them for this activity.

As to the job's site, Teresina was the most cited, congruent with the demographic information reported by participants, who mentioned most frequently the State's capital as a place for residency.

Regarding the professional practice, it was found that most of the undergraduates have already had more than one employment tie, however, currently, the majority has just one job. It was found that the average period of permanence in an employment was 12.7 months. These data points out to professionals who do not have been settled for a long time in the first jobs, probably because they were at the beginning of their careers, in the phase of identification and definition for the field where they intended to act and specialize.

A study [17] examined the period of permanence in the first three nursing jobs of undergraduates, and found that they usually remained between one to six months or seven to twelve months in these occupations. For the author, the undergraduates that pass through high turnover at the beginning of their career, for dissatisfaction in the first jobs or seeking to specialize, as well as seeking better opportunities, which tend to appear, as they acquire more professional experience.

As for the predominant activity in the professional practice of undergraduates, assistive function was identified as the most cited among the participants. The same variable was studied by other authors $[9,13,16]$, and the results showed that the welfare function predominated among the nursing undergraduates taking part in their research, with occurrences going from $40 \%$ to $87 \%$.
When asked about performing NCS, considerable part of the undergraduates confirmed to perform the activity. However, while investigating what steps were carried out, we identified Nursing Data Collection (Nursing History) as the single phase referred to by all participants who claimed to perform NCS.

The Resolution of the Nursing Federal Council (COFEN) No. 358/2009 [19], states that the nursing process should be conducted in all environments in which the nursing professional care takes place, and comprises the steps of Nursing Data Collection (Nursing History), Nursing Diagnosis, Nursing Planning, Implementation (Nursing Prescription) and Nursing Evaluation (evolution).

Thus, it was observed in this research that among the undergraduates who declared acting in health care, not all use NCS, and among those who perform it, those do not meet all the steps. The fact is also emphasized that the undergraduates cite nursing prescription completion more frequently that the nursing diagnosis, what is understood that some are conducting prescriptions with no diagnosis.

One denotes with these results that there are inconsistencies in the practice of undergraduate nurses in this study, since that NCS achievement is mandatory in health care activity, and is the main subsidy for nurses' autonomy, for being supported by scientific principle and guaranteeing the quality of provided care.

Considering that the Pedagogic Project of CGE/ UFPI [12], includes contents that offer to enable the student to perform the clinical judgment of the patient, in the disciplines: Semiology and Semitechnical for the nursing and nursing care Methodology, it is believed to be a gap in this teaching-learning process, which should be better investigated.

With respect to the participation in professional associations, one distinguished the absence of binding for the undergraduates in this study to such organizations, however, often related to the Brazilian Nursing Association (ABEn) and the Nursing Unions. 
In this regard, it is believed that the nurse should seek to enter into relationships with others in collective discussion rooms, exposing ideas, disseminating knowledge, and interacting in social and political movements, for achieving conscious, critical, and politicized practice [19].

Given the low frequency of undergraduates in this study on participation in professional associations, one lamented the finding, since that organizations such as ABEn, Nursing Unions and Association of Experts in Nursing are rooms that enable nurses to expand the discussions of topics related to the profession, collectively, resulting in professional growth and improvements in healthcare.

\section{Conclusion}

As in other professions, the young undergraduates of CGE/UFPI sought to consolidate their career before the social engagements of marriage and children. One positively visualized the practices for the professional development, because the search for professional qualification by means of post-graduation was significant.

The average individual income and the number of undergraduates outside the labor market or who had just one job also show nurses at the beginning of their careers, with a view to multi-employment being common in the profession, with the consequent increase in income.

As for the characteristics of the professional practice of undergraduate nurses, greater integration in the hospital area was highlighted, followed by the public health area, which, in a certain way, confronts the emphasis of education policies and health consolidated in the recent years, which gives priority to the training of health professionals to work in primary care.

It is visualized, in this aspect, that researches related to the labor market for the nurse is important in order to guide the approaches on the curricular content of the Graduation in Nursing courses, in view that to endow the undergraduate with abilities and knowledge during the under graduation does not guarantee their employment capability, if their abilities do not supply the or are not adjusted to the available employment chances.

In addition, studies on this theme subsidize the operation and creation of new degree courses in nursing, which are often designed without evaluating existing job opportunities for the professionals that will be launched in the labor market, generating unemployment, and disappointment among the nurses. The increase in the offer of professionals causes the nurses to be submitted to jobs with low pay, and employers drop wages for the category [or vice-versa], generating devaluation and lack of recognition for the profession.

Another result being considered was the practice of undergraduates in nursing care, where some do not perform NCS and those who perform do not do in its entirety. It could be perceived that the undergraduates have chance to learn NCS in the Course, however, its applicability finds obstacles well more complex in the care environment, exceeding the competence and skill of the nurse in executing it.

It is understandable that NCS is one of the principal means for nurses to conquer autonomy and professional recognition in front of society, clients and other professionals of the health team, but given the results, is still perceived as something far from being achieved.

In this respect, managers of health services have a key role for NCS applicability, when including it in the service philosophy and providing human and operational resources that allow the nurse to perform it. In addition, customer awareness on NCS, and its importance for them are also determining factors to make the practice of nursing process something concrete and valued.

This way, when the characteristics of the nurse workplace do not allow for executing the nursing process, the professional should be able to change such a reality, and not suiting themselves to it. 
Therefore, it is not enough to prepare the undergraduate to perform NCS; the INSTITUTIONS OF HIGHER EDUCATION need to provide them with critical and political conscience, so that they may transform their practice reality.

It is therefore concluded that accomplishing the studies with the undergraduates should be done periodically by the nursing schools, so that their results may enable reflections, changes, and/or improvements in the curriculum and in the teaching-learning process of undergraduate courses in nursing.

\section{References}

1. Ministério da Educação. Conselho Nacional de Educação. Câmara de Educação Superior. Parecer CNE/ CES n. 1133, de 7 agosto de 2001. Institui as diretrizes curriculares nacionais dos cursos de graduação em enfermagem, medicina e nutrição. Diário Oficial da República Federativa do Brasil [online] Brasília (DF), 03 out. 2001. Disponível em: (12 fev. 2014)

2. Ministério da Educação. Conselho Nacional de Educação. Câmara de Educação Superior. Resolução CNE/CES n. 3, de 7 novembro de 2001. Institui as diretrizes curriculares nacionais do curso de graduação em Enfermagem. Diário Oficial da República Federativa do Brasil. Brasília (DF), 9 nov. 2001. Seção 1, p. 37.

3. Camelo SHH, Mishima SM, Pereira MCA, Laus AM, Porto HS. Desenvolvendo uma metodologia para acompanhamento do egresso de enfermagem de uma Instituição de Ensino Superior. Rev Eletr Enf. 2015;17(2):247-56.

4. Canever BP, Gomes DC, Jesus BH, Spillere LB, Prado ML, Backes VMS. Processo de formação e inserção no mercado de trabalho: uma visão dos egressos de enfermagem. Rev Gaúcha Enferm. 2014;35(1):87-93.

5. Vieira MAS, Luís PSO, Conceição VSD, Edvane BL. Evaluation with undergraduation graduates in nursing: national publications 2001-2011. Hist enferm Rev eletronica;2014;5(1): 35-53.

6. Colenci R, Berti HW. Formação profissional e inserção no mercado de trabalho: percepções de egressos de graduação em enfermagem. Rev esc enferm USP. 2012; 46(1):158-66.

7. Souza NVDO, Correia LM, Cunha LS, Eccard J, Patrício RA, Antunes TC S. O egresso de enfermagem da FENF/UERJ no mundo do trabalho. Rev esc enferm USP. 2011; 45(1):250-7.

8. Branquinho NCSS, Bezerra ALQ. Egressos de Enfermagem: uma revisão sistemática da literatura. VIII Congresso de Pesquisa Ensino e Extensão. Universidade Federal de Goiás. 2011.

9. Passos SL, Machado PRF, Martins ERC, Francisco MTR, Silva AP, Fonte VRF. O egresso de enfermagem de uma universidade privada e a sua inserção no Mercado de trabalho. R saud corp amb cuid. 2013; 1(1):177-91.
10. Universidade Federal do Piauí. Departamento de Enfermagem. Projeto Pedagógico do Curso de Graduação em Enfermagem. 2012.

11. Souza SNDH, Miyadahira AMZ. O desenvolvimento de competências no curso de graduação em Enfermagem: percepção de egressos. Cienc Cuid Saude 2012; 11(supl.):24350.

12. Universidade Federal do Piauí. Departamento de Enfermagem. Projeto Pedagógico do Curso de Graduação em Enfermagem, 2007.

13. Santos MG, Holanda FL, Carolla DC, Traldi MC. Egressos do Curso de Enfermagem da Faculdade de Medicina de Jundiaí: perfil e inserção no mercado de trabalho. Perspect Med.2014; 25(1):33-42.

14. Maciente AN, Nascimento PAMM, Assis LRS. As ocupações de nível superior com maiores ganhos salariais entre 2009 e 2012. Radar: tecnologia, produção e comércio exterior. 2013;27(7):5568.

15. Oliveira FMM, Vasconcelos MIO, Vieira IPGF, Ferreira AGN, Cavalcante ASP, Teófilo FS. Inserção de Egressos do Curso de Graduação em Enfermagem no Mercado de Trabalho. SANARE.2014; 13(1): 92-8.

16. Zborowski IP, Jabur MRL, Lúcio DE, Sperandio DB, Dias E. Nurses alumni: expectations and opportunities in the market. CuidArte Enferm;2009;3(1):41-5.

17. Püschel VAA, Inácio MP, Pucci PPA. Inserção dos egressos da Escola de Enfermagem da USP no mercado de trabalho: facilidades e dificuldades. Rev esc enferm USP. 2009;43(3): 53542.

18. Conselho Federal de Enfermagem. Resolução n 358, de 15 de outubro de 2009. Dispõe sobre a Sistematização da Assistência de Enfermagem e a implementação do processo de enfermagem em ambientes, públicos ou privados, em que ocorre o cuidado profissional de Enfermagem, e dá outras providências. Available from: http://site.portalcofen.gov.br/node/4384

19. Lima WCB, Sampaio SF. Political competence of nurses: literature findings. Rev gaúch enferm. 2007; 28(4):564-9.
Publish in International Archives of Medicine

International Archives of Medicine is an open access journal publishing articles encompassing all aspects of medical science and clinical practice. IAM is considered a megajournal with independent sections on all areas of medicine. IAM is a really international journal with authors and board members from all around the world. The journal is widely indexed and classified Q2 in category Medicine. 